PROSTHETIC TREATMENT OF THE EDENTULOUS PATIENT 


\title{
PROSTHETIC TREATMENT OF THE EDENTULOUS PATIENT
}

\author{
R. M. BASKER, DDS, MGDSRCS, LDSRCS \\ Professor of Dental Prosthetics, University of Leeds;
}

Consultant in Restorative Dentistry, Leeds General Infirmary and Associated Hospitals Trust; Examiner, MGDS of the Royal College of Surgeons of England; formerly External Examiner, the Universities of Birmingham, Bristol, Dundee, London, Manchester, Newcastle-upon-Tyne, Sheffield and Wales

\section{J. C. DAVENPORT, PhD, BDS, FDSRCS}

Senior Lecturer in Dental Prosthetics, University of Birmingham; Consultant Dental Surgeon,

South Birmingham Health Authority; External Examiner, the Universities of Wales, Dublin and Leeds; formerly External Examiner, University of Glasgow

\section{H. R. TOMLIN, DDS, LDSRCS}

Emeritus Professor of Dental Prosthetics, University of Birmingham; formerly External Examiner, Queen's University Belfast and the Universities of Edinburgh, London, Leeds and Wales

\section{THIRD EDITION}

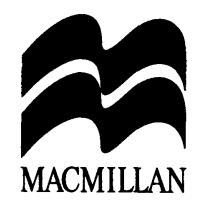


All rights reserved. No reproduction, copy or transmission of this publication may be made without written permission.

No paragraph of this publication may be reproduced, copied or transmitted save with written permission or in accordance with the provisions of the Copyright, Designs and Patents Act 1988, or under the terms of any licence permitting limited copying issued by the Copyright Licensing Agency, 90 Tottenham Court Road, London WIP 9HE.

Any person who does any unauthorised act in relation to this publication may be liable to criminal prosecution and civil claims for damages.

First edition 1976

Reprinted four times

Second edition 1983

Third edition 1992

\section{Published by}

MACMILLAN PRESS LTD

Houndmills, Basingstoke, Hampshire RG2I $2 X S$

and London

Companies and representatives

throughout the world

ISBN 978-0-333-56705-0 ISBN 978-1-349-21869-1 (eBook)

DOI 10.1007/978-1-349-21869-1

A catalogue record for this book is available from the British Library.
$\begin{array}{lllllll}11 & 10 & 9 & 8 & 7 & 6 & 5\end{array}$

$\begin{array}{llllll}03 & 02 & 01 & 00 & 99 & 98\end{array}$ 
To our families 


\section{Contents}

Preface to the First Edition

Preface to the Third Edition

Foreword to the First Edition John Osborne

viii

Acknowledgements

$\mathbf{x}$

$\mathrm{xi}$

xii

1 An Appraisal of the Complete-denture Situation

2 The Patient's Contribution to Prosthetic Treatment

3 Transition from Natural to Artificial Dentition 31

4 Stability of Dentures 52

5 Jaw Relations - Theoretical Considerations 66

6 Assessment of the Patient 77

7 The Relevance of Existing Dentures 92

8 Preparation of the Mouth 121

9 Impressions 142

10 Recording Jaw Relations - Clinical Procedures 168

11 Dentures and Muscles 196

12 Try-in Procedures 217

13 Fitting Complete Dentures 232

14 Recall Procedures 249

15 Some Complete-denture Problems 257

$\begin{array}{ll}\text { Index } & 280\end{array}$ 


\section{Preface to the First Edition}

Over the years, the writings and researches of many prosthetists have hastened the swing from the mechanistic to the biological approach in complete-denture prosthetics. With this change in outlook there has been an increasing awareness of the tremendous variation that is found in edentulous patients: the variation in quality of the denture-bearing tissues and their response to function, the varying behaviour of the jaw mechanisms, the differing patterns of muscle function which act upon the dentures and, finally, the varying and often unexpected response of patients to the challenge of wearing complete dentures. Clinical techniques have been devised and modified to meet these variations.

Effective clinical procedures are built on a sound theoretical basis and in this text an attempt is made to present the theoretical background in the early chapters and to use this background to justify the clinical techniques which are subsequently described. In an effort to economise in an age of ever-rising costs, repetition has been avoided wherever possible and frequent references are made to other parts of the book where particular items are considered in greater detail.

Because of the varied response mentioned earlier, it is not sufficient for the clinician to possess only one basic technique of constructing complete dentures, no matter how sophisticated. Instead, it is of the utmost importance to develop a flexible approach when devising a treatment plan and to have available alternative methods of treatment appropriate to the needs of the individual patient. We have avoided presenting detailed descriptions of clinical techniques in the belief that once the background information is understood one can become proficient only by chairside tuition and clinical experience. Only practice makes perfect and the greater one's clinical experience, the more one will have learnt from successes and failures.

The background information on materials science, pre-prosthetic surgery and prosthetic laboratory techniques has not been included as these subjects are covered fully in well-established texts which are readily available to students.

The purpose of the bibliography at the end of each chapter is two-fold. First, to include references which may be related directly to clinical techniques described in the text, and second, to provide a selection of key 
sources which will enable the reader to commence a search of the literature on a particular topic of interest.

Inevitably, the replacement of lost tissues by complete dentures is a compromise; in spite of modern developments there remain limitations to this aspect of restorative dentistry and some patients continue to have difficulty in coming to terms with these limitations. Because of the understandable demands of the patients for good-looking, comfortable and efficient complete dentures, no matter what the problems in the mouth, complete-denture prosthetics remains a demanding and challenging aspect of a dentist's clinical life.

Birmingham, 1976

R.M.B.

J.C.D.

H.R.T. 


\section{Preface to the Third Edition}

In preparing the third edition we have again attempted to preserve the principles which governed the structure of the book in the first instance. At the same time we have undertaken a thorough revision of the text bearing in mind the changes which have occurred during the last eight years - perhaps the most significant being the continuing fall in numbers of edentulous patients together with the transition to the completely artificial dentition being generally made somewhat later in life.

High levels of full clearances in previous years mean that there are still large numbers of people, indeed the majority of those over 65 years of age, with complete dentures. There will therefore remain a considerable need for replacement dentures for many years to come. However, those individuals requiring full clearances and complete dentures for the first time will be increasingly elderly and will become fewer in number. The consequence of this changing pattern is that, although there will be a gradual reduction in the volume of complete-denture prosthetics over the next 50 years, the work will become more demanding as it increasingly relates to the welfare of elderly patients.

In the new edition, we have introduced a specific section on the problems of elderly patients. Also included for the first time is a section on the prevention of cross-infection. Major alterations have been made to topics such as copy dentures, the treatment of mucosal lesions and the management of those people who suffer from the burning mouth syndrome. We have broadened the approach of the chapters dealing with patient assessment and muscular control of dentures. All other chapters have been revised thoroughly to take account of the changes in technique and the approach to treatment that have occurred since the second edition was published.

Leeds, Birmingham and Gresford, 1991 R.M.B.

J.C.D.

H.R.T. 


\section{Foreword to the First Edition}

This addition to prosthetic literature must be widely and warmly welcomed. For a number of years there has been a shortage of British texts for students concerning the edentulous patient. The authors have, correctly, stressed the serious problems that more and more frequently present themselves now that life expectancy is on the increase and the average age of the edentulous is advancing. The dental profession is becoming aware of the particular geriatric situations it now has to face and this book will undoubtedly help in solving many prosthetic geriatric problems.

Emphasis has been placed more upon general principles than upon the minutiae of clinical or technical operative detail. Given a sound basic understanding of the principles to be observed in the treatment of the edentulous, chairside experience rapidly perfects each individual's manipulative skills.

Being not unfamiliar with the labours involved in producing textbooks one is conscious of the time and effort that has gone into the preparation of this book. It should achieve all the success that these efforts of one's former colleagues deserve.

Shalfleet, Isle of Wight, 1975

JOHN OSBORNE 


\section{Acknowledgements}

We are most grateful to Professor R. J. Anderson, Dr O. J. Corrado and Dr C. J. Watson for checking sections of the latest edition and offering their constructive comments. For those sections of the book which have not required revision this time we should like to acknowledge the invaluable assistance of other colleagues for their contributions to the earlier editions.

We acknowledge with thanks the permission of the Editor of the British Dental Journal to reproduce Figures 3.3 and 7.10, and the permission of Munksgaard International Publishers Ltd to reproduce Figure 1.3 which is a modified version of an illustration that appeared in Geriatric Dentistry edited by Poul Holm-Pedersen and Harold Löe. We would also like to thank Mr J. P. Ralph and Dr C. J. Watson for allowing us to reproduce Figures 3.2 and 8.9 respectively.

Our grateful thanks are extended to all the members of the Medical and Dental Illustration Unit of the University of Leeds and the Photographic Department of the Dental School at the University of Birmingham for skilfully preparing the new illustrative material.

Finally, the support and contributions by our secretaries, Mrs Gill Bunney and Miss Alison Peacock, have been invaluable in bringing this project to fruition. 